\title{
Peat moss: A hyper-sorbent for oil spill cleanup - a review
}

\author{
Saumya Pandey \& Afroz Alam* \\ Department of Bioscience and Biotechnology, Banasthali Vidyapith (Rajasthan), India
}

\section{Article history}

Received: 07 June 2019

Accepted: 18 July 2019

Published: 01 October 2019

\section{Publisher}

Horizon e-Publishing Group

\author{
*Correspondence \\ Afroz Alam \\ \afrozalamsafvi@gmail.com
}

\begin{abstract}
Peat moss, a well-known hyper-sorbent is now gaining attention for its utilization in oilspill cleanup techniques because of its cost-effectiveness, biodegradability and relatively high oil absorption capacities. This review mainly emphasis on the characteristic features of the peat moss such as high porosity and large surface area which make it an efficient natural sorbent material for cleaning up oil spills. There are several products which have been developed from the peat moss and are commercially available in the market for oil spill cleanup.
\end{abstract}

Keywords: Natural sorbents; Mosses; Oil-sorption; Biodegradability; Hydrophobicity

Citation: Pandey S, Alam A. Peat moss: A hyper-sorbent for oil spill cleanup - a review. Plant Science Today 2019;6(4):416-419. https://doi.org/10.14719/pst.2019.6.4.586

Copyright: (C) Pandey \& Alam (2019). This is an open-access article distributed under the terms of the Creative Commons Attribution License, which permits unrestricted use, distribution, and reproduction in any medium, provided the original author and source are credited (https://creativecommons.org/licenses/by/4.0/).

Indexing: Plant Science Today is covered by Scopus, Web of Science, BIOSIS Previews, ESCI, CAS, AGRIS, CABI, Google Scholar, etc. Full list at http://www.plantsciencetoday.online

\section{Introduction}

The oil pollution of water resources which are mainly caused by routine shipping, dumping, industrial effluent or oil spills has now become a serious global issue (1). The oil spill imposes serious threat to the environment and causes ecological imbalance (2). It spreads on the surface of the water and not only affects the aquatic flora and fauna but also causes a harmful effect on the terrestrial animals and other creatures $(3,4)$. An oil spill from the source of an accident can also spread over the wide range of water surface via wind or water current, and after sometime it is subjected to decomposition by physical, chemical or biological process (5). The key steps involved in oil degradation are evaporation, dispersion, emulsion, sedimentation, oxidation and biodegradation $(6,7)$. However, several factors such as type, physical properties, amount of oil, location of spill, weathers, oxygen concentration in water and strain of microorganisms present at spill sites have an effect on the biodegradation process of oil $(8,9)$.

To address the problems that arises due to oil spills, several remediation measures have been taken worldwide which can be broadly classified into four categories, a) Physical/mechanical methods (10) such as use of skimmers, pumps, boom, mechanical separators, etc., b) Chemical methods such as use of chemical dispersant (11), c) Thermal methods such as burning of oil spills (12), d) Biological technologies involve the use of biosorbents and microorganisms (13). In addition to the type of oil spilled, the choice of techniques all depends upon several environmental conditions such as temperature, wind current, waves and location of the oil spill (14). Also, the techniques used should be cost-effective but do not 
cause the negative impact on the environment. Such as the in situ burning is the least expensive technique to remove an oil spill but it causes air pollution (15). Thus, the frequent incident of oil spill and the inability of conventional techniques to overcome this problem have drawn the attention of researchers worldwide for develop in eco-friendly, low cost and effective materials for cleaning oil from oil-impacted areas.

Among all the aforementioned methods, the sorbent cleaning up method is one of the most efficient methods for removal of oil from the water surface $(6,16)$. Presently, around 200 different types of sorbent materials are available which can be broadly classified into four major groups inorganic, natural organic and organomineral and synthetic $(17,18)$. Due to slow degradability shown by the synthetic sorbents, the biomaterials based sorbent such as straw, sawdust, cellulosic kapok fiber, cotton fibers, corn corb, milkweed floss and peat moss are gaining special attention among the researchers (17). The natural sorbents are inexpensive, renewable resources and biodegradable $(19,20)$.

Peat moss emerges as one of the promising raw material for the development of inexpensive and eco-friendly natural sorbent that do not require regeneration (21). It is formed by the partial decomposition of mosses and other living materials such as sedges, grasses, shrubs or trees under waterlogged conditions (22). They are abundantly found in many regions of the world covering approximately $1-2 \%$ of the earth surface (23). The chief components of peat moss are lignin, cellulose, fulvic and humic acids that contain several functional moieties such as carboxylic, phenolic and hydroxylic groups (24, 25). The high adsorption capacity of peat moss towards metals is mainly due to the presence of these functional groups (25). The peat moss has a highly porous structure and thus provides the large surface area for adsorption of pollutant. Several products such as Enviropeat, Spill-Sorb, Peat Sorb, Sphag Sorb, etc. are already available in the market that is developed from pure and high-quality Sphagnum moss. They are low cost, biodegradable, easy to handle, non-abrasive, nonleaching, non-toxic, non-hazardous, silica-free and is easy to apply (manually or mechanically). It is used mainly for environmental spill cleanup and remediation purposes by industries, airports, railways, marine vessels, harbors, etc.

\section{Characteristics of peat moss as hyper-sorbent of the oil spill}

The hyper-sorbent property of peat moss is mainly due to its physical structure and chemical composition. The features of peat moss associated with its use in oil spill cleanup are discussed below:

\section{High-sorption capacity}

The high sorption capacity of the peat moss is mainly due to two significant structural features, 1) a large number of pores which provides large surface area for molecules to adsorb to walls, 2) large number of capillary spaces which enables the absorption and retention of hydrocarbons (26, 27). It has been observed that higher sorption capacity in moss Sphagnum magellanicum in comparison with Sphagnum sancto-josephense, as former moss possess larger sized cellular pores and more capillary spaces which facilitate entry of hydrocarbons more easily (28).

The lower hydrophobic property of peat moss offers major drawback for its use in oil spill cleanup $(2,29)$. However, hydrophobicity can be increased by the destruction of the hydrophilic compound via various chemical modifications and temperature treatment methods. The hydrophobic property and oil sorption capacity of peat moss can be increased by the low-temperature pyrolysis method (27). This method involves the dehydration, physical destruction and chemical modifications of the hydrophilic-oxygencontaining compounds. Hydrophobicity of peat moss can be increased via two methods 1) chemical modification of cellulose to carboxymethyl cellulose via esterification with acetic anhydride, 2) heat treatment of peat moss at the temperature from $100-400{ }^{\circ} \mathrm{C}$ (30). The oil sorption capacity of acetylated peat moss (7.60 - 8 $\mathrm{g} / \mathrm{g}$ ) and carbonized peat moss (14.2 - $15.7 \mathrm{~g} / \mathrm{g})$ was reported to be higher than peat moss $(5.8 \mathrm{~g} / \mathrm{g})$.

\section{High buoyancy}

The peat moss has high buoyancy and thus can float on the water surface and can be recovered easily. Olga et al. (30) investigated comparative hydrocarbon adsorption affinity of several natural sorbents such as Russian peat moss (Sphagnum Dill), Canadian Sphagnum peat moss (Nature sorb), charcoal and sawdust and reported high buoyancy in both the types of peat mosses. Also, the modified peat mosses such as the acetylated peat moss and low-temperature carbonized peat moss were also reported to be exhibit higherbuoyancy (30).

\section{Rate of absorption}

The rate of absorption of oil is higher for the lighter hydrocarbons. This is due to lower viscosity of oil which allows high-pressure gradient in capillary structure, resulting in speedy entry of hydrocarbons in capillary spaces of peat moss. Nino et al. (28) determined sorption kinetic of Sphagnum moss and reported that maximum sorption was achieved in less than one minute for all the hydrocarbons.

\section{Particle size (Granularity) of peat moss}

For light hydrocarbons, the sorption capacity of fine granularity peat moss (mesh 80) was reported to be higher than coarse granularity (mesh 30 ) 
peat moss. Whereas, the coarse granularity peat moss (mesh 30) gave better results with heavy hydrocarbons. The predominant phenomenon for sorption of light and heavy hydrocarbons is absorption and adsorption respectively (28). The fine granularity peat moss has a greater surface area of contact and thus provides easy penetration of less viscous hydrocarbons in capillary spaces. The highly viscous heavy hydrocarbons lead to clogging of the pore and thus it can easily adsorb to the surface of spaces formed between the structures of coarse particle size peat moss.

\section{oil retention}

Due to high-sorption capacities of peat moss, the probability of desorption of hydrocarbons from pores are very low and thus prevents the chance of secondary contaminations during the recovery process (30). Thus, the peat moss has high oil retention property.

\section{Conclusion}

The peat moss is apotential biomaterial for the development of oil sorbents. Due to its large surface area and porosity of structure, it shows high oil sorption capacity. However, the hydrophobicity of peat moss is low which may lead to greater water absorptivity when applied on oil spill over water surfaces. The hydrophobic property of peat moss can also be enhanced by the chemical modification and temperature treatment methods. In addition, high buoyancy and adsorption rate has facilitated its easy recovery from the water surface. Thus, peat moss is economical, eco-friendly, biodegradable and highsorption capacity natural sorbent material for oil spill cleanup. In the future, the inherent characteristics of peat moss in combination with innovative technology can be further utilized for the development of more efficient oil spill cleanup techniques.

\section{Acknowledgement}

The authors are thankful to Prof. Aditya Shastri, Vice Chancellor, Banasthali Vidyapith for his encouragement and support.

\section{References}

1. Si-Zhong Y, Hui-Jun J, Zhi W, Rui-Xi H, Yan-Jun J, Xiu-Mei L, Shao-Peng Y. Bioremediation of oil spills in cold environments: A review. Pedosphere. 2009; 19:371-81. https://doi.org/10.1016/S1002-0160(09)60128-4

2. Adebajo MO, Frost RL, Kloprogge JT, Carmody O, Kokot S. Porous materials for oil spill cleanup: A review of synthesis and absorbing properties. J Porous Mat. 2003; 10:159-70. https://doi.org/10.1023/A:1027484117065

3. Brody TM, Di-Bianca, P, Krysa J. Analysis of inland crude oil spill threats, vulnerabilities, and emergency response in the midwest United States. Risk Anal. 2010;
32:1741-49. 6924.2012.01813.x

https://doi.org/10.1111/j.1539-

4. Barron MG. Ecological impacts of the deepwater Horizon oil spill: implications for immunotoxicity. Toxicol Pathol. 2012; 40:315-20. https://doi.org/10.1177/0192623311428474

5. Doshi B, Sillanp M, Kalliola S. A review of bio-based materials for oil spill treatment. Water Res. 2018; 135:262-77. https://doi.org/10.1016/j.watres.2018.02.034

6. Paulauskienė T, Zabukas V, Vaitiekunas P, Zukauskaite $A$, Kvedaras V. Investigation of volatile organic compounds (VOCs) emission beyond the territory of oil terminals during different seasons. JEnviron Eng Landsc Manag. 2011; 19:44-52. https://doi.org/10.3846/16486897.2011.558994

7. Liu Z, Liu J, Zhu Q, Wu W. 2012. The weathering of oil after the Deepwater Horizon oil spill: insights from the chemical composition of the oil from the sea surface, salt marshes and sediments. Environ Res Lett. 2012; 7:035302. https://doi.org/10.1088/1748-9326/7/3/035302

8. Mažeikienė A, Vaiškūnaitė R, Vaišis V. Oil removal from runoff with natural sorbing filter fillers. J Environ Manag. 2014; 141:155-60. https://doi.org/10.1016/j.jenvman.2013.12.037

9. Paulauskiene T, Jucike I. Aquatic oil spill cleanup using natural sorbents. Environ Sci Pollut Res. 2015; 19:1487481. https://doi.org/10.1007/s11356-015-4725-y

10. Fingas, M. Oil spill science and technology. Gulf professional Publishing, 2016. pp. 1078.

11. Graham L, Hale C, Maung-Douglass E, Sempier S, Swann L, Wilson M. Oil spill science: Chemical dispersants and their role in oil spill response. MASGP. 2016; 15:015.

12. Evans DD, Mulholland GW, Baum HR, Walton WD, McGrattan KB. In situ burning of oil spills. J Res NBS. 2001; 106:231.

13. Azubuike CC, Chikere CB, Okpokwasili GC. Bioremediation techniques-classification based on site of application: principles, advantages, limitations and prospects. World J Microbiol Biotechnol. 2016; 32:180. https://doi.org/10.1007/s11274-016-2137-x

14. Teas C, Kalligeros S, Zanikos F, Stournas S, Lois E, Anastopoulos G. Investigation of the effectiveness of absorbent materials in oil spills clean up. Desalination 2001; 140:259-64. $\quad$ https://doi.org/10.1016/S00119164(01)00375-7

15. Mullin JV, Champ MA. Introduction/Overview to in situ burning of oil spills. Spill Sci Technol Bull. 2003; 8: 32330. https://doi.org/10.1016/S1353-2561(03)00076-8

16. Karan CP, Rengasamy RS, Das D. Oil spill cleanup by structured fibre assembly. IJFTR. 2011; 190-200.

17. Olga VR, Darina VI, Alexandr AI, Alexandra AO. Cleanup of water surface from oil spills using natural sorbent materials. Procedia Chem. 2014; 10:145-50. https://doi.org/10.1016/j.proche.2014.10.025

18. Ifelebuegu AO, Johnson A. Nonconventional lowcost cellulose-and keratinbased biopolymeric sorbents for oil/water separation and spill cleanup: a review.Crit Rev Environ Sci Technol. 2017; 47:964-1001. https://doi.org/10.1080/10643389.2017.1318620

19. Abdullah MA, Rahmah AU, Man Z. Physicochemical and sorption characteristics of Malaysian Ceiba pentandra (L.) Gaertn. as natural oil sorbent. J Hazard Mater. 2010; 177:683-91. https://doi.org/10.1016/j.jhazmat.2009.12.085

20. Vlaev L, Petkov P, Dimitrov A, Genieva S. Cleanup of water polluted with crude oil or diesel fuel using rice 
husks ash. J Taiwan Inst Chem E. 2011; 42:957-64. https://doi.org/10.1016/j.jtice.2011.04.004

21. Onishchenko Dv, Reva Vp. Formation of Carbon Nanofibers on the basis of Sphagnum moss. Coke Chem. 2012; 55:286-88.

22. Klavins M, Purmalis O. Characterization of humic acids from raised bog peat. Materials Science and Applied Chemistry 2013; 29:95-100. https://doi.org/10.2478/ljc2013-0010

23. Cojocaru C, Macoveanu M, Cretescu I. Peat based sorbents for the removal of oil spills from water surface: Application of artificial neural network modeling. Colloids and Surfaces A: Physicochemical and Engineering Aspects. 2011; 384:675-88. https://doi.org/10.1016/j.colsurfa.2011.05.036

24. Ghaly RA, Pyke JB, Ghaly AE, Ugursal VI. Remediation of diesel-oil-contaminated soil using peat, energy sources. A: Recovery, utilization, and environmental effects. Chemosphere. 1999; 21:785-99.

25. Brown P A, Gill SA, Allen SJ. Metal removal from wastewater using peat. Water Res. 2000; 34:3907-16. https://doi.org/10.1016/S0043-1354(00)00152-4
26. Cohen AD, Rollins MS, Zunic WM, Durig WM. Effects of chemical and physical differences in peats on their ability to extract hydrocarbons from water. Water Res. 1991; 25:1047-60. $\quad$ https://doi.org/10.1016/00431354(91)90198-Y

27. Klavins M, Porshnov D. Development of a new peat based oil sorbent using peat pyrolysis. Environ Technol. 2013;34:1577-82. https://doi.org/10.1080/09593330.2012.758668

28. Niño GR, González DO, Fonseca A, Ruiz CM. Tropical's Sphagnum peat moss, an efficient alternative to clean up oil spills. Enpromer 2015; 2:1-6.

29. Novosolova L, Sirotkina E. Peat based sorbents for treatment of polluted environments. Solid Fuel Chemistry 2008;4:64-77.

30. Olga R, Viktor R, Alexander I, Zinnur S, Alexandra P. Adsorption of hydrocarbons using natural adsorbents of plant origin. Procedia Chem. 2015;15:231-36. https://doi.org/10.1016/j.proche.2015.10.037 